\title{
Biochemical Taxonomy of Crenicichla (Pisces: Perciformes: Cichlidae) of the Iguaçu River, Brazil
}

\author{
Erasmo Renesto*, Cláudio Henrique Zawadzki and Eloísa Revaldaves \\ Universidade Estadual de Maringá, Núcleo de Pesquisa em Limnologia Ictiologia e Aqüicultura, Av. Colombo, \\ 5790, 87020-900 Maringá, PR, Brazil
}

\begin{abstract}
Samples of Crenicichla iguassuensis and a morph from the Iguaçu River which differed from $\mathrm{C}$. iguassuensis by its lips morphology were examined by isozyme starch electrophoresis technique. The analysis of 27 enzyme loci exhibited a genetic identity of 0.993 between the two morphs. No diagnostic locus was found that permitted to distinguish the two Crenicichla morphs. The data obtained in this investigation did not support the existence of two distinct species for this genus in the Iguaçu River, which suggested that the morphs stood for two polymorphic forms of Crenicichlaiguassuensis.
\end{abstract}

Key words: Isozyme polymorphism; biochemical systematics; biochemical taxonomy; genetics of Crenicichla; genetic identity

\section{INTRODUCTION}

The biological species concept is based on the reproductive isolation of groups of true-breeding populations from other such groups (Mayr, 1970). For organisms that survive and reproduce in captivity or laboratory, the existence of reproductive isolating mechanisms may be directly verified. However, for those that cannot be maintained in laboratory conditions, such as Crenicichla, this task may be complex and sometimes, extremely difficult. Two different approaches are used to avoid this difficulty. One of them, which is largely employed by the Taxonomists, is the analysis of morphological characters; the other is the analysis of genetically codified protein or nucleic acids differences.

According to the species concept, two populations or morphs, should share the same alleles, provided they are conspecific. Thus, the absence of heterozygotes in a population that contains both homozygotes is conclusive for the existence of reproductive isolating mechanisms, i. e., two species (Richardson et al., 1986; Thorpe \& SoléCava, 1994). In this case, such locus is called diagnostic locus. Even though no diagnostic locus is found, the species status might be settled by Nei's genetic identity measure (Nei, 1972, 1978). According to Avise (1974) and Thorpe (1982), the Nei's (1972) genetic identity (I) between two populations of the same species ranges from 0.80 to 1.00 whilst it ranges from 0.10 to 0.85 between two species of the same genus. Thus, if the Nei's (1972) genetic identity between two populations or morphs falls below 0.80 they are distinct species of the same genus, and if it falls below 0.10, they are species belonging to different genus.

\footnotetext{
* Author for correspondence
} 
Garavello et al. (1997) reported that only three native species of cichlids were known in the Iguaçu River before 1997: Geophagus brasiliensis Quoy \& Gaimard, 1824, Crenicichla iguassuensis Haseman, 1911, Cichlasoma facetum Jenyns, 1848 and the exotic species Tilapia rendallii (Boulenger, 1898). They found another type of Crenicichla (Crenicichla sp.), which was distinguished from $C$. iguassuensis by its large,

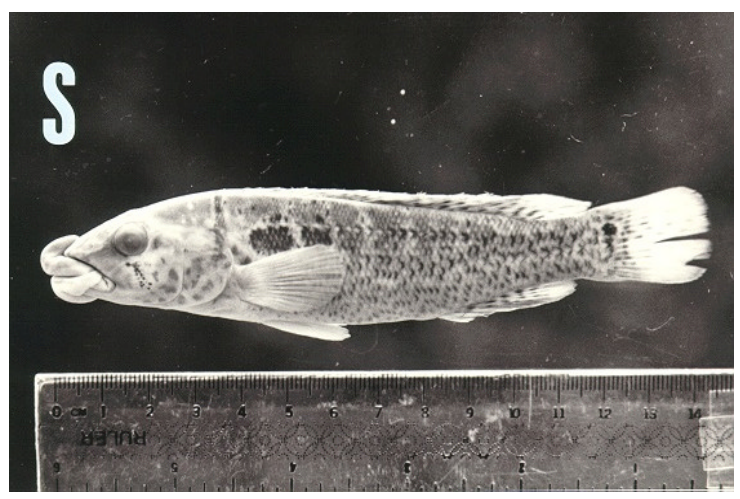

fleshy and lobed lips. Both of them have fishes as their chief diet although they eat some invertebrates (Hahn et al., 1997) and have a standard length between 8 and $25 \mathrm{~cm}$ (BeneditoCecílio \& Agostinho, 1997).

This work intended to verify if Crenicichla sp. was a distinct species from $C$. iguassuensis by the analysis of isozyme characters as discussed by Buth \& Murphy (1999).

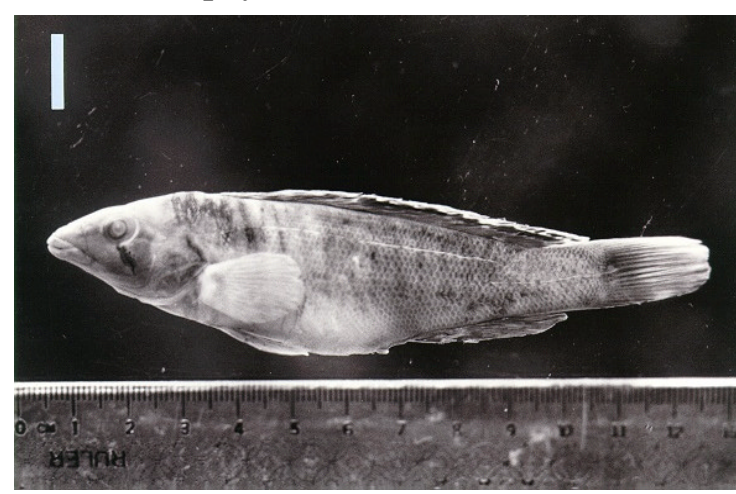

Figure 1 - Crenicichla Iguassuensis (I) and Crenicichla sp. (S)

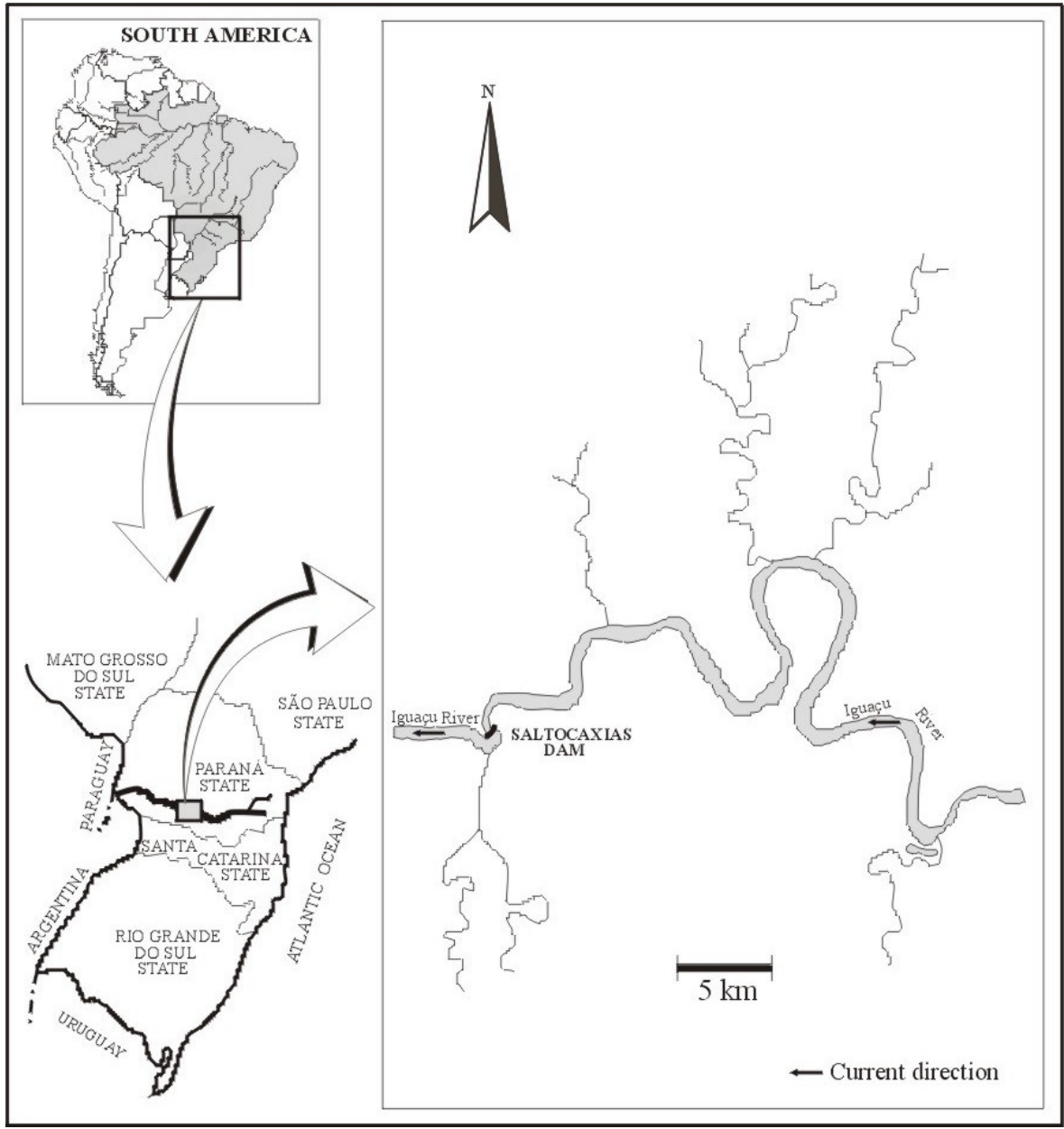

Figure 2 - Geographic localization of the stretch of Iguaçu River where the samples were taken. 


\section{MATERIALS AND METHODS}

The specimens of Crenicichla iguassuensis and Crenicichla sp. (Fig. 1) were collected in the Iguaçu River between April and September 1997 at the locality where it is now Salto Caxias Reservoir (Fig. 2).The liver, white muscle and heart were removed from living fish and frozen in liquid nitrogen. For analysis, the tissues were homogenized with plastic pestles in $1.5 \mathrm{ml}$ Eppendorf tubes with four drops of $0.2 \mathrm{M}$ Tris/ $\mathrm{HCl}$ buffer, $\mathrm{pH}$ 7.5. Carbon tetrachlorate in 1:2 concentration (tissue:tetrachlorate) was added when liver was homogenized (Pasteur et al., 1988). The homogenized samples were centrifuged at $25,000 \mathrm{rpm}(44,720 \mathrm{x} \mathrm{g})$ for 30 minutes at $1-5^{\circ} \mathrm{C}$. The supernatant fractions were submitted to horizontal electrophoresis in 13\% corn starch (penetrose 30) covered with an ice pack. Two buffer systems were used: Tris 0.135
M/Citric Acid $0.043 \mathrm{M}, \mathrm{pH} 7.0$ (TC) diluted 1:15 for gel and Tris $0.18 \mathrm{M} /$ Boric acid $0.1 \mathrm{M} / \mathrm{EDTA}$ $0.004 \mathrm{M} \mathrm{pH} 8.6$ (TBE) diluted 1:4 for gel, according to (Boyer et al., 1963). Electrophoresis was performed for $6 \mathrm{~h}$ at $5^{\circ} \mathrm{C}$ with voltage gradients of $250 \mathrm{~V}$ for the Tris-Citrate gels, and $450 \mathrm{~V}$ for the Tris-Borate-EDTA gels. Gels were horizontally sliced and then incubated in a staining solution appropriate to each enzyme.

The assayed enzymes and buffer systems are shown in Table 1.The procedures described by Aebersold et al. (1987) were used to visualise the specific isozymes but for AAT Morizot \& Schimidt (1990) method was used.The genetic interpretation of enzymatic patterns was based on the quaternary structure of the enzymes (Ward et al., 1992). The nomenclature utilised was that proposed by Shaklee et al. (1990). The data were analysed using the software Biosys 1 (Swofford \& Selander, 1981).

Table 1 - Names, abbreviations, Enzyme Commission number (E.C. $n^{\circ}$ ), tissues, buffers, quaternary structure (Q.S.) and number of loci for each assayed enzyme in Crenicichla iguassuensis and Crenicichla sp. from the Iguaçu River.

\begin{tabular}{|c|c|c|c|c|c|}
\hline Enzyme (abbreviation) & E.C. $n^{\circ}$ & Tissue & Buffer & Q. S. & Loci \\
\hline Acid phosphatase (ACP) & 3.1.3.2 & $\mathrm{L}$ & TBE & M & 1 \\
\hline Alcohol dehydrogenase (ADH) & 1.1.1.1 & $\mathrm{L}$ & TBE & $\mathrm{D}$ & 1 \\
\hline Aspartate aminotransferase (AAT) & 2.6.1.1 & $\mathrm{L}$ & TBE & $\mathrm{D}$ & 3 \\
\hline Esterase (EST) & 3.1.1.1 & $\mathrm{L}$ & TBE & M & 2 \\
\hline Glucose dehydrogenase (GDH) & 1.1.1.47 & $\mathrm{L}$ & TBE & $\mathrm{D}$ & 1 \\
\hline Glycerol-3-phosphate dehydrogenase (G3PDH) & 1.1.1.8 & M & $\mathrm{TC}$ & $\mathrm{D}$ & 1 \\
\hline Glucose-6-phosphate dehydrogenease (G6PDH) & 1.1.1.49 & $\mathrm{L}$ & TBE & $\mathrm{D}$ & 2 \\
\hline Glucose-6-phosphate isomerase (GPI) & 5.3.1.9 & $\mathrm{L}, \mathrm{H}$ & $\mathrm{TC}$ & $\mathrm{D}$ & 2 \\
\hline Iditol dehydrogenase (IDDH) & 1.1.1.14 & $\mathrm{L}$ & TC & $\mathrm{T}$ & 1 \\
\hline Isocitrate dehydrogenase (IDHP) & 1.1.1.42 & $\mathrm{L}, \mathrm{H}$ & TC & $\mathrm{D}$ & 2 \\
\hline Lactate dehydrogenase (LDH) & 1.1.1.27 & $\mathrm{L}, \mathrm{H}$ & TC & $\mathrm{T}$ & 2 \\
\hline Malate dehydrogenase (MDH) & 1.1.1.37 & $\mathrm{L}, \mathrm{H}$ & TC & $\mathrm{D}$ & 3 \\
\hline Malic enzyme (MEP) & 1.1.1.40 & $\mathrm{L}, \mathrm{H}$ & TC & $\mathrm{T}$ & 2 \\
\hline Peroxidase (PER) & 1.11.1.7 & $\mathrm{L}$ & TBE & $\mathrm{T}$ & 2 \\
\hline Phosphoglucomutase (PGM) & 5.4 .2 .2 & $\mathrm{~L}, \mathrm{H}$ & $\mathrm{TC}$ & M & 1 \\
\hline Superoxide dismutase (SOD) & 1.15.1.1 & $\mathrm{L}$ & TBE & $\mathrm{D}$ & 1 \\
\hline
\end{tabular}

$\mathrm{L}=$ liver; $\mathrm{M}=$ muscle $; \mathrm{H}=$ heart; $\mathrm{TBE}=$ Tris/Borate/EDTA; $\mathrm{TC}=$ Tris/Citrate; $\mathrm{D}=$ dimeric $\mathrm{M}=$ monomeric; $\mathrm{T}=$ tetrameric.

\section{RESULTS}

Sixteen enzymatic systems of five Crenicichla sp. and 29 C. iguassuensis were analyzed, allowing to detect twenty seven presumed loci (Table 1).
Figure 3 shows the diagrammatic representation of the twenty eight electrophoretic phenotypes obtained for each enzyme system as well as their genetic interpretation. 

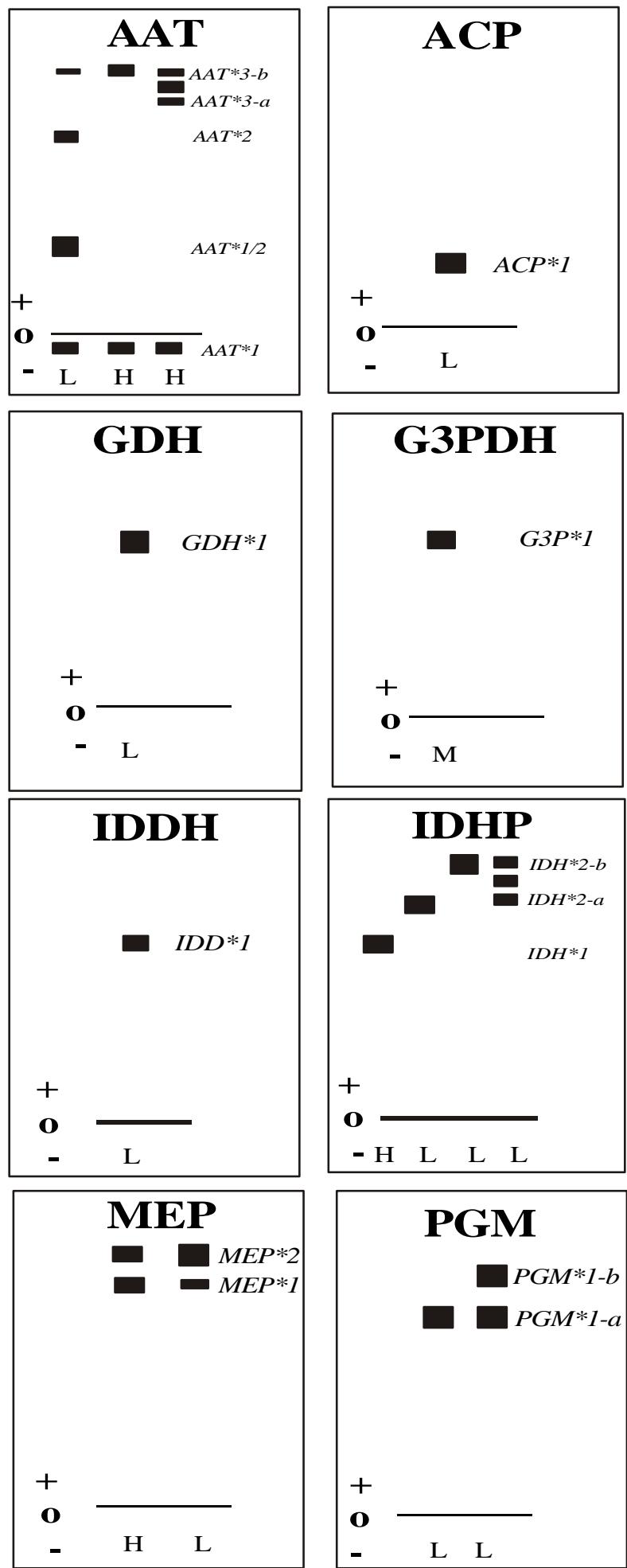
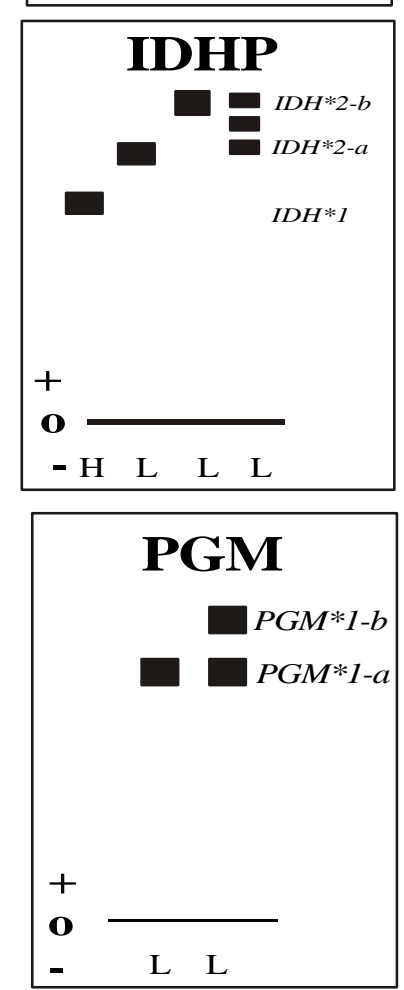
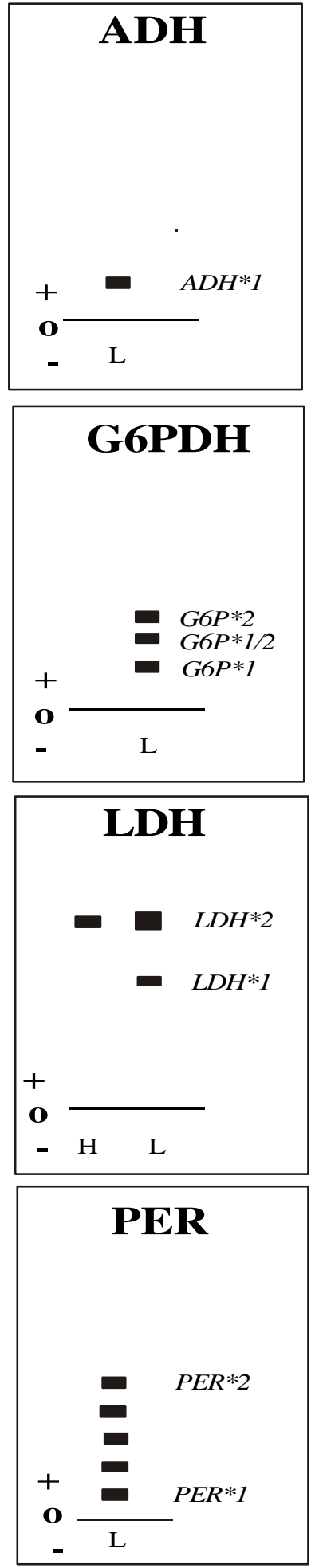
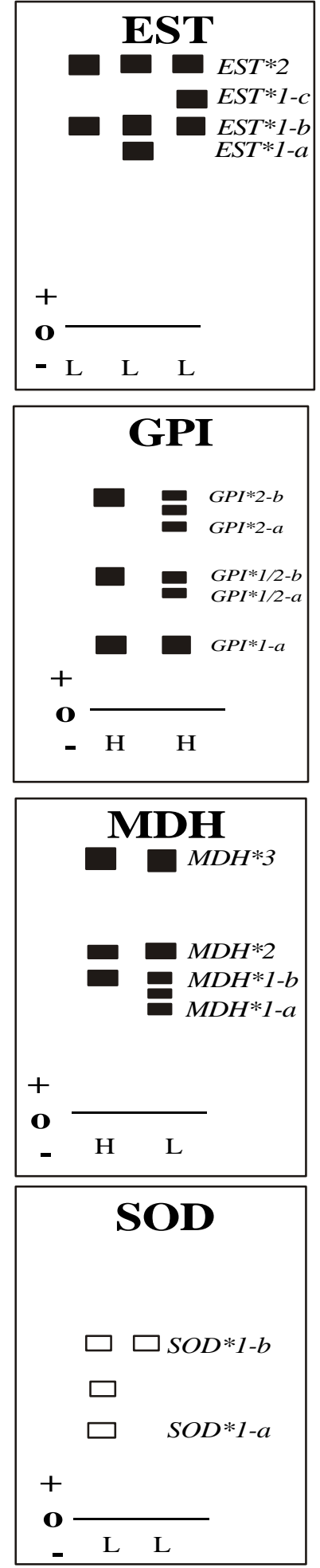

Figure 3 - Schematic representation of enzymatic phenotypes resulting from the analysis of 16 enzymatic systems of Crenicichla iguassuensis and Crenicichla sp. and their genetic interpretations. $\mathrm{H}=$ heart, $\mathrm{L}=$ liver, $\mathrm{M}=$ muscle.

AAT: Were detected one cathodic and three anodic bands in the liver samples. Heart samples showed phenotypes with one cathodic and one anodic band. One individual exhibited three anodic bands in the heart samples. Because AAT is a dimeric enzyme, these phenotypes could be interpreted as due to three loci with heterodimer formation between the products of $A A T^{*} 1$ and $A A T * 2$ loci. Locus $A A T * 2$ did not express itself in 
the heart samples. The three anodic bands found in heart samples represented a heterozygote at $A A T * 3$

ACP. This monomeric enzyme exhibited only one band in all the individuals of the two morphs, indicating the presence of a single monomorphic locus.

ADH: This dimeric enzyme had activity in the liver only. A single band of activity was observed in all specimens due to a single monomorphic locus.

EST: This monomeric enzyme had its expression restricted to the liver and exhibited three phenotypes. It might be coded by one monomorphic and one polymorphic locus.

GDH: This enzyme was expressed in the liver samples only. All the individuals showed a single band.

G3PDH: Although it appeared in all the three tissues, its expression was better in muscle. All the individuals showed a single band.

G6PDH. This enzyme appeared in the liver only with three bands in all the individuals. Because this enzyme might have dimeric or tetrameric quaternary structure (Ward et al., 1992) the three bands might be due to two monomorphic loci.

GPI: All the analyzed specimens had three bands, typical of the effect of two homozygous loci with heterodimer formation. Only one individual had six bands, which resulted from the expression of one homozygous and one heterozygous locus.

IDDH: Only one band was detected in all individuals bringing out the presence of a single monomorphic locus.

IDHP: This dimeric enzyme presented a single band in the heart and one or three bands in the liver all of them more anodic than that of heart. These phenotypes may be explained by the presence of one monomorphic locus with expression limited to the heart, and one locus with two alleles which was expressed in the liver only.

LDH: heart samples showed only one band while those of the liver had two bands. The more anodic one was more intense. Since this enzyme has tetrameric quaternary structure in all known vertebrates, this pattern might be due to the expression of two monomorphic loci without heterotetramer formation.

MDH: Three bands were detected in the liver and the heart. The more anodic one was more intense. This pattern was interpreted as codified by three loci without heterodimer formation. Two individuals exhibited five bands, resulted from heterozygosis in locus $M D H^{*} 1$.

MEP: Two bands were detected in all tissues. This tetrameric enzyme might be codified by two monomorphic loci.

PGM: A single band was present in all tissues of all but one individual, which exhibited two bands. This monomeric enzyme might be codified by one locus with two alleles.

SOD. This dimeric enzyme exhibited phenotypes with one and three bands, characteristic of one locus with two alleles.

Table 2 shows the allele frequencies at each locus of each fish morph. Of all the 27 presumptive loci, $25.9 \%$ were polymorphic in C. iguassuensis and $14 \%$ were polymorphic in Crenicichla sp. All the loci were in Hardy-Weinberg equilibrium. The unbiased estimated mean heterozygosity per locus (Nei, 1978) was $0.033 \pm 0.016$ for $C$. iguassuensis. and $0.063 \pm 0.030$ for Crenicichla sp. The Nei's unbiased genetic identity and unbiased genetic distance (Nei, 1978) between the two morphs were $\boldsymbol{I}=0.993$ and $\boldsymbol{D}=0.007$, respectively.

\section{DISCUSSION}

Since the cichlid fishes are largely used in aquaculture, several genetic studies have been done with the aim of improving the species identification in view of the difficulty in identifying the different species. This is due to overlapping in morphological characteristics, as well as crossbreeding between some species (Degani \& Levcovitch, 1991). Although the morphological differences result from genetic differences, morphometric characters are liable to environmental modification. 
Table 2 - Allele frequency estimates for Crenicichla iguassuensis and Crenicichla sp. from the Iguaçu River. $\mathrm{n}=$ number of analyzed specimens

\begin{tabular}{|c|c|c|}
\hline LOCUS & $\begin{array}{l}\text { Crenicichla } \\
\text { iguassuensis } \\
(\mathrm{n}=29)\end{array}$ & $\begin{array}{l}\text { Crenicichla sp. } \\
(\mathrm{n}=5)\end{array}$ \\
\hline$A C P * 1-a$ & 1.000 & 1.000 \\
\hline$A A T^{*} 1-a$ & 1.000 & 1.000 \\
\hline$A A T^{* 2-a}$ & 1.000 & 1.000 \\
\hline$A A T^{*} 3-a$ & 0.017 & 0.000 \\
\hline$A A T * 3-b$ & 0.983 & 1.000 \\
\hline$A D H^{* 1-a}$ & 1.000 & 1.000 \\
\hline$E S T^{*} 1-a$ & 0.121 & 0.200 \\
\hline$E S T^{*} 1-b$ & 0.810 & 0.800 \\
\hline$E S T^{*} 1-c$ & 0.069 & 0.000 \\
\hline$E S T^{*} 2-a$ & 1.000 & 1.000 \\
\hline$G D H^{* 1-a}$ & 1.000 & 1.000 \\
\hline$G 3 P^{*} 1-a$ & 1.000 & 1.000 \\
\hline$G 6 P^{*} 1-a$ & 1.000 & 1.000 \\
\hline$G 6 P * 2-a$ & 1.000 & 1.000 \\
\hline$G P I * 1-a$ & 1.000 & 1.000 \\
\hline$G P I * 2-a$ & 0.983 & 1.000 \\
\hline$G P I * 2-b$ & 0.017 & 0.000 \\
\hline$I D H^{*} 1-a$ & 1.000 & 1.000 \\
\hline$I D H * 2-a$ & 0.845 & 0.400 \\
\hline$I D H * 2-b$ & 0.155 & 0.600 \\
\hline$I D D * 1-a$ & 1.000 & 1.000 \\
\hline$L D H^{*} 1-a$ & 1.000 & 1.000 \\
\hline$L D H^{* 2-a}$ & 1.000 & 1.000 \\
\hline$M D H^{*} 1-a$ & 0.034 & 0.200 \\
\hline$M D H^{*} 1-b$ & 0.966 & 0.800 \\
\hline$M D H^{* 2-a}$ & 1.000 & 1.000 \\
\hline$M D H^{*} 3-a$ & 1.000 & 1.000 \\
\hline$M E P^{*} 1-a$ & 1.000 & 1.000 \\
\hline$M E P * 2-a$ & 1.000 & 1.000 \\
\hline$P G M * 1-a$ & 0.983 & 1.000 \\
\hline$P G M * 1-b$ & 0.017 & 0.000 \\
\hline$P E R^{*} 1-a$ & 1.000 & 1.000 \\
\hline$P E R * 2-a$ & 1.000 & 1.000 \\
\hline$S O D * 1-a$ & 0.069 & 0.300 \\
\hline$S O D * 1-b$ & 0.931 & 0.700 \\
\hline
\end{tabular}

Besides, several populations are morphologically different without reproductive isolating mechanisms among them (races), while true species may be formed without morphological differentiation (sibling species). The large and fleshy lips of Crenicichla sp. may be an adaptation to some environmental conditions. There are several cases of fishes that develop adaptive structures to some period of their life cycle or to some environmental conditions. SaintPaul \& Soares (1988) reported that Mylossoma duriventris and $M$. aurea develop an extension of inferior lip to breath the Oxygen of the water surface during hypoxia periods. Val \& AlmeidaVal (1995) reported that this phenomenon occur in other fishes besides Mylossoma, such as Colossoma macropomum, Piaractus brachipomum, and Brycon cf. Cephalum. Machado-Allison (1990) described secondary sexual structures, such as spines, tubercles, and large lips developed during the reproductive period in Pseudoauchenipterus galeatus and Entomocorus gameroi.

Lucena \& Kullander (1992) in their study of some Crenicichla species from Uruguay River were able to describe a species (Crenicichla tendybaguassu) that showed large and fleshy lips like Crenicichla sp. of Iguaçu River. They found that this characteristic occurred in several cichlid fishes of Africa and Nicaragua. These authors cited that Barlow \& Munsey (1976) reported that there was much individual variation in lip development degree and the lips regressed in captive specimens. They also cited Bussing (1975) which observed a large variation in lip hypertrophy of Cichlasoma tuba from Central America. According to Lucena $\&$ Kullander (op. cit.) the only South American cichlid with greatly hypertrophied lips was Gymnogeophagus labiatus from the coast of Rio Grande do Sul State (Brazil). In view of the findings among Central American cichlids, the use of lip morphology as a species character must be done with caution.

Genetic differences among populations may be assessed by enzyme or DNA electrophoresis. One of the advantages of these techniques is that genetic characters are less subject to environmental modifications than morphological ones. Another advantage is that enzymes are almost invariably codominant. This basically means that heterozygotes have different phenotypes from homozygotes. Identifying the homozygotes and the heterozygotes makes the calculation of gene frequencies very simple.

Kornfield \& Koehn (1975), analyzed nine enzymatic systems of Cichlasoma cyanoguttatum and two other unidentified species from Mexico and found heterozygosity values between zero and 0.036. Bank et al. (1989) studied eighteen enzymatic systems of fifteen species of African cichlids and detect heterozygosity values between 0.021 and 0.047. Degani \& Levcovitch (1991) studied nine enzymatic systems of seven cichlid species of Israel but they did not estimate the heterozygosity.

The genetic variability estimated for Crenicichla sp. (0.063) and C. iguassuensis (0.033) in our sample were high compared with that of other 
cichlid species already investigated. The genetic similarity between the two morphs, measured by the Nei's (1978) unbiased standard genetic identity was very high and lies in the range of values for conspecific populations (Thorpe, 1982). This result did not corroborate nor exclude the hypothesis that Crenicichla sp. could be a distinct species from $C$. iguassuensis. It was concluded that Crenicichla sp. was a morphologic variation of $C$. iguassuensis rather than a distinct species. Still, the available information were insufficient to explain the origin and function of the observed hypertrophied lips.

\section{ACKNOWLEDGMENTS}

The authors would like to thank to COPEL (Companhia Paranaense de Energia Elétrica) for financial support, to Dr. Oscar Shibata and Carla S. Pavanelli for the suggestions on the manuscript, to Celso Ikedo for making the photos and to Harumi I. Suzuki for collecting the fish samples.

\section{RESUMO}

Amostras de Crenicichla iguassuensis e de um morfótipo do rio Iguaçu que difere de $C$. iguassuensis pela morfologia dos lábios foram analisadas pela técnica da eletroforese de isozimas em gel de amido. A análise de 27 loci enzimáticos revelou uma identidade genética de 0,993 entre as duas formas. Não foi encontrado nenhum locus diagnóstico que permitisse diferenciar os dois morfótipos de Crenicichla. Os dados obtidos nesta pesquisa não apóiam a existência de duas espécies distintas do gênero Crenicichla no rio Iguaçu. Os dados sugerem que as duas formas representam um polimorfismo da espécie Crenicichla iguassuensis.

\section{REFERENCES}

Aebersold, P. B., Winans, G. A., Teel, D. J., Milner, G. B. and Utter, F. M. (1987), Manual for starch gel electrophoresis: a method for the detection of genetic variation. NOAA Technical Report NMFS 61.

Avise, J. C. (1974), Systematic value of electrophoretic data. Systematic Zoology, 23 (1/4), 465-481.
Bank, F. H. V., Grant, W. S. \& Ferreira, J. T. (1989), Electrophoretically detectable genic data for fifteen southern African cichlids. J. Fish Biol., 34, 465-483.

Benedito-Cecílio, E. \& Agostinho, A. A. (1997), Estrutura das populações de peixes do reservatório de Segredo. In - Reservatório de Segredo: bases ecológicas para o manejo, eds. A. A. Agostinho \& L. C. Gomes. EDUEM, Maringá, pp. 113-139.

Boyer, S. H., Fainer, D. C. \& Naughton, M. A. (1963), Myoglobin inherited structural variation in man. Science, 140, 1228-1231.

Buth, D. G. \& Murphy, R.W. (1999), The use of isozyme characters in systematic studies. Biochem. Syst. Ecol., 27, 117-129.

Degani, G. \& Levcovitch, Y. (1991), Electrophoretic variation in some cichlid species in Israel. Comp. Biochem. Physiol., 99B (2), 464-467.

Garavello, J. C.; Pavanelli, C. S. \& Suzuki, H. I. (1997), Caracterização da ictiofauna do rio Iguaçu. In - Reservatório de Segredo - bases ecológicas para $o$ manejo, eds. A. A. Agostinho \& L. C. Gomes. EDUEM, Maringá, pp. 61-84.

Hahn, N. S., Fugi, R., Almeida, V. L. L., Russo, M. R. \& Loureiro, V. E. (1997), Dieta e atividade alimentar de peixes do reservatório de Segredo. In Reservatório de Segredo: bases ecológicas para o manejo, eds. A. A. Agostinho \& L. C. Gomes. EDUEM, Maringá, pp. 141-162.

Kornfield, I. L. \& Koehn, R. K. (1975), Genetic variation and speciation in New World cichlids. Evolution, 29, 427-437.

Lucena, C. A. S. de \& Kullander, S. O. (1992), The Crenicichla (Teleostei: Cichlidae) species of the Uruguai River drainage in Brazil. Ichthyol. Explor. Freshwaters, 3 (2), 97-160.

Machado-Allison, A. (1990), Ecologia de los peces de las areas inundables de los llanos de Venezuela. Interciencia, 15 (6), 411-423.

Mayr, e. (1970) Population, Species and Evolution. University of Harvard Press. Cmbridge.

Morizot, D. C. \& Schmidt, M. E. (1990), Starch gel electrophoresis and histochemical visualization of proteins. In Electrophoretic and isoelectric focusing techniques in fisheries management, ed. D. H. Whitmore. CRC Press, Boca Raton, pp. 23-80.

Nei, M. (1972), Genetic distance between populations. Am. Nat., 106 (949), 283-291.

Nei, M. (1978), Estimation of average of heterozygosity and genetic distance from small number of individuals. Genetics, 89, 583-590.

Pasteur, N., Pasteur, G., Bonhomme, F., Catalan, J. \& Britton-Davidian, J. (1988), Practical isozyme genetics. Ellis Horwood Limited, Chichester. 
Richardson, B. J., Baverstock, P. R. \& Adams, M. (1986), Allozyme electrophoresis. A handbook for animal Systematics and populations studies, Academic Press, North Ride.

Saint-Paul, U \& Soares, M. G. M. (1988), Ecomorphological adaptation to oxygen deficiency in Amazon floodplains by Serrasalmidae fish o the genus Mylossoma. J. Fish Biol., 32, 231-236.

Shaklee, J. B., Allendorf, F. W., Morizot, D. C. \& Whitt, G. S. (1990). Gene nomenclature in proteincoding loci in fish. Trans. Am. Fish. Soc.,119, 2-15.

Swofford, D. L. \& Selander, R. B. (1981). Biosys-1: a FORTRAN program for the comprehensive analysis and electrophoretic data in populations genetics and systematics. J. Hered., 72, 281-283.
Thorpe, J. P. (1982), The molecular clock hypothesis: biochemical evolution, genetic differentiation and systematics. Ann. Rev. Ecol. Syst., 13, 139-168.

Thorpe, J. P. \& Sole-Cava, A. M. (1994), The use of allozyme electrophoresis in invertebrate Systematics. Zool. Scr., 23, 3-18.

Val, A. L. \& Almeida-Val, V. M. F. (1995), Fishes of the Amazon and their environment. Springer-Verlag, Berlin.

Ward, R. D., Skibinski, D. O. F.\& Woodward, M. (1992), Protein heterozygosity, protein structure, and taxonomic differentiation. Evol. Biol., 26, 73-159.

Received: May 02, 1999; Revised: September 28, 1999; Accepted: August 07, 2000. 